\title{
2 \\ An Overview of the Luxury Fashion Industry
}

\subsection{The Concept of Luxury and Its Attributes}

\subsubsection{The Concept of Luxury}

From an etymological perspective, the word luxury comes from the Latin "luxus" which means superabundance, excess in the way of life or a display of wealth aimed at satisfying desires that transcend real needs. As Sombart states, luxury is any expense that exceeds what is necessary (Sombart 1967). Hence, the concept of luxury is closely linked to human needs, and a concrete definition of luxury depends on the specific time and society under analysis and might vary within these aspects. There is no unique definition of "luxury"; on the contrary, it takes on different forms and meanings in relation to the context of space and time as well as according to the perspective of the study. Luxury has a nomadic, multipurpose character that is difficult to trace back to a unique and definitive concept.

In this context, eventually, the term luxury can take on a negative meaning, linked to images of exaggeration and immoderation. It is no coincidence that from the root "lux" also originates the word "luxuria" 
which can be translated as "exuberance, profusion, luxury" and "lascivious and voluptuous life" (Lipovetsky and Roux 2003). The term luxury also recalls the Greek lemma "loxos" (Mattia 2013), which means growth in an oblique way, which can also be interpreted as displacement and deviation from the norm. The reference to the idea of detachment is also discussed by Kapferer (2012) who identifies its origin in the Latin "luxation", i.e., distance, and suggests that luxury describes a considerable departure from the usual way of satisfying needs. This sphere is usually connected to experiences, objects and services and is marked by a high symbolic value for which the consumer is willing to spend exorbitant amounts well above the average price of the category to which the product belongs, which in turn is definitely not anchored to the simple sum of production costs. The term therefore suggests a sort of deviation and a distortion in which excess and distinction are mixed; it describes an attitude involving enthusiasm for all that is outside the norm.

It is not by chance that the meaning of the term oscillates between two opposing polarities: on the one hand, the representation of wealth, deserving recognition of the economic and social success linked to the capacities of the individual and, on the other hand, bad taste and the absence of measure originating from the exclusive attachment to all that is superfluous and material. From these considerations, two different interpretations of the concept of luxury emerge: on the one hand, it portrays a form of ostentatious consumption that motivates the need to acquire the good to exhibit status and wealth; on the other hand, it refers to the emotional dimension (hedonistic consumption) favoring the search for gratification and personal satisfaction. Luxury in this case means giving oneself the best and seeking one's own pleasure and well-being.

From this brief etymological analysis, we can already perceive the ambivalence of the concept of luxury, as both positive and negative, and how this subject encompasses different interpretations and meanings. The meaning attributed to luxury has undoubtedly undergone a metamorphosis over time, changing form and value in different historical periods.

According to Lipovetsky and Roux (Lipovetsky and Roux 2003), luxury did not begin with the simple production of expensive objects 
and the ostentation of opulence and sumptuousness. However, one can find an ethics of luxury even in prehistory. Before being a symbol of material civilization, "Paleolithic" luxury was a cultural phenomenon, a mental attitude that saw the affirmation of man as a social being and not an animal. Another reason for the emergence of luxury, apart from an economic and materialistic perspective, is religion where luxury takes on a sacred form, made up of symbolism and closeness to the divinities. Luxury items were perfect presents for the divinities of ancient Egyptian or Roman empires. With the development of the great civilizations of the ancient world, luxury goods increasingly referred to the idea of wealth, privilege and power along with the satisfaction of abundance that goes beyond mere basic needs. Nevertheless, in this phase, negative connotations were also observed in some cultures. For example, in ancient Greece, the habit of indulging in luxury was considered a threat to society because the satisfaction derived from it could have transferred the focus of citizens from the polis to private life (Brun and Castelli 2013). Today, this is still a word whose meaning depends on multiple and very different perspectives. For example, in some religions, luxury expenses are a byproduct of the weakness of human soul, while in others they are considered the tangible proof of mundane success which is in turn linked to divine grace.

Even without a detailed analysis of all stages of the evolution of the concept of luxury in different eras, societies or religions, it is nevertheless important to identify the birth of the so-called modern concept of luxury, focusing on the most recent years. Particularly, many authors identify a transitional phase in the conception of luxury after the wave of the second industrial revolution (Danziger 2005).

\subsubsection{The New Luxury}

At the end of the nineteenth century, the term luxury acquired a new meaning related to complacency in what is excellent and expensive and to the pleasure of enjoying something comfortable beyond what is strictly necessary (Brun and Castelli 2013). For the majority of the nineteenth century, the concept of luxury was still affected by the aristocratic and 
artisanal model in which goods were crafted manually by expert artisans and relied on high quality, and eventually rare, raw materials, and were sold mainly in the local market. The irruption of modernity and of the industrial revolution changed at the very heart the approach to and the meaning of luxury.

Industrialization has led to enormous productivity gains and higher production volumes of more standard items to be sold beyond local geographical borders, laying the foundations for what are today global luxury companies.

Initially, the new logic of luxury fashion found its best representative image in haute couture such that luxury became a "creative industry" for the first time (Lipovetsky and Roux 2003). Luxury thus tends to lose most of its negative connotations, such as decadence and estrangement from morality. During the twentieth century, luxury became a term for describing a product, an industry or an expensive and high-quality object that flaunts elegance and sumptuousness (Danziger 2005).

For a long time, luxury had been synonymous with haute couture, a model based essentially on tailoring in which the designer is the guardian of the aesthetic tradition of the wealthiest classes. Each dress was a unique piece, tailor made and a work of art born to celebrate the power and prestige of the aristocracy. In time, this traditional and sartorial approach towards fashion started changing. For example, in the 1920s, designer Coco Chanel revolutionized the traditional look, enunciating an idea of fashion that was more modern and dynamic. Chanel completely changed the mood of the suit to make it comfortable and practical. However, the revolution did not happen by chance. In fact, in times of war, Chanel had to use any tissues available and also started using the jersey, and the suit became more attuned to the body without markings of the waist for a men's jacket with pockets and straight skirts reaching the knee. Functional, practical and comfortable, it would become the Maison's iconic suit.

From the 1960s onwards, the democratization of society introduced a sort of aesthetic reformism that broke with the idea of tradition: the first collections accessible to the emerging classes were created by designers such as Pierre Cardin and Yves Saint Laurent. In 1966, Yves Saint Laurent resumed the style launched by the diva Marlene Dietrich, 
who wore the jacket with trousers for the first time and made it her own. This was the prêt-à-porter with dresses designed for everyday life and made more affordable. In terms of communication, the identification of the brand with the figure-myth of the designer imposed its own diktat on fashion victims in the form of a total look that was increasing at that time.

During the 1980s, the industrial organization system finally became established in the world of fashion. It was at this time that Italian designers such as Versace, Armani and Trussardi overtook their French cousins in terms of volume and turnover. The competition between Milan and Paris, the two European capitals of fashion, reflects the contrast between the French model of haute couture and the Italian model of prêt-à-porter favored by licensing policies and brand extension, which sanctioned the union between designers and companies. If in the past the experience of luxury was reserved for a privileged few, today it has broadened its horizons, extending to new groups of buyers and new categories of products (cosmetics, jeans, accessories, food and consumer electronics).

The world of luxury has now abandoned the aura of sacredness and uniqueness that had characterized it up to that point to enthusiastically marry the cause of innovation and the future: the Italian style defined the expression of a quality of life that was not reserved only for the most elitist strata of the population and found its counterpart in the peculiarity of the production model of the industrial districts; it was capable of responding with great flexibility to the growing complexity of demand.

During the 1990s, a post-fashion logic was established characterized by the proliferation of styles and sources of inspirations. Designers shaped collections but were also inspired by the emerging phenomenon of street style. It was a situation that significantly expanded the possibilities of the choice of the increasingly evolved and demanding consumer who could now assemble her own outfits by mixing and matching clothes and accessories from different designers. In this context, the product responds to the more complex needs and has multiple meanings and therefore takes on a central role in the communicative value of the brand.

Since the second half of the twentieth century, there has been a trend towards massification, leading to a transformation of both the 
supply and the demand in the fashion industry. The growing mass production has seen the flourishing of the "democratization of luxury" which has brought not only the wealthiest people to the market but also, increasingly, a large part of the population as a whole, thus breaking down the strong social stratification. The so-called "Neo-Luxury" offers high-quality products and services at a more affordable price to the majority of middle-class consumers. This transformation was illustrated by Silverstein et al. (2008) through the phenomenon of trading-up: the desire and intention to pay a premium price for goods that have a high degree of quality, aesthetic taste and attractiveness compared to products in the same category but that are not so unapproachable. People are thus inclined to spend more on the product categories they are interested in and in some selected brands (trading-up) and less on less interesting product classes (producing the so-called trading down) to be able to invest savings in new luxury products. This evolution also generates different interpretations of luxury, understood as social identity, search for experiences and emotions, the desire to be satisfied with oneself and gratification. Luxury becomes beauty, pleasure and dream and accompanies the consumer in an experience capable of involving the multiplicity of the senses.

Interestingly, Kapferer (2012) emphasizes that the term premium is not synonymous of luxury and that the there is a discontinuity between the two. Something luxury is somehow more special than premium products. According to Danziger (2005), the label of the new luxury should not be associated only with the democratization of luxury, that is, simply referring to a more accessible luxury, but the real paradigm shift would lie in the way consumers define the new luxury, that is, as an experience or a feeling. While the old luxury only involves things, the new luxury regards the whole consumer experience.

Simultaneously, the focus of attention shifts from the intrinsic characteristics of the product to what it represents. Essentially, a new competitive arena is created in which companies win or lose on the basis of creativity, innovation and brand strength and are called upon to enrich objects with symbolic values regardless of the traditional requirements of rarity and exclusivity. It is a highly profitable strategy for 
companies, which involves trading-up, a purchasing behavior increasingly widespread among consumers willing to pay a premium price to get possession of products of superior quality and high emotional content. More and more people are talking about luxury and not only fashion. This terminology indicates a substantial change in the sector in the recent years. Nowadays, fashion companies no longer sell clothes for people to cover themselves but sell a lifestyle, a way of being. Clothes and accessories have become tools to express identity.

Diesel, Starbucks and BMW are companies that have made use of the phenomenon of accessible luxury. Unlike traditional luxury goods (e.g., Chanel, Rolls Royce and Cartier) whose price confines them to elite consumers, neo-luxury goods can generate higher sales volumes despite higher prices compared to that of other products in the same product category. Thus, exclusivity marries mass appeal. In fact, although new luxury goods cost approximately $200 \%$ more than those of competitors, they remain within the reach of a substantial proportion of consumers who are willing to own products with superior functional, technical and emotional benefits; they balance costs by purchasing goods at minimum prices in categories that are not of a similar kind of importance.

The competitiveness and market positioning of luxury companies require a renewed ability to understand these changes to provide an adequate response to the needs of a more attentive and sophisticated consumption. Prada, Pirelli PZero and Balenciaga are examples of firms that have taken up this challenge, updating luxury through the avantgarde, the enhancement of comfort, practicality and the exaggeration of technological detail. Gucci also shatters the compact and aristocratic image of the brand to present itself in a more modern, bold and alluring manner.

In the background, there is a new consumer figure who does not interpret in a static and univocally determined way belonging to a specific lifestyle: she is a "centaur" customer, able to move with great agility and is informed and wise in her choices; her behavior is less predictable and aimed at satisfying her own specific needs, sometimes conflicting and not classifiable according to a single model of behavior.

It is luxury with a human face that no longer leaves anyone out but rather aims to understand an ever-widening world. From the stage of 
the Triennale di Milano 2018, the guest of the conference Next Design Perspectives, Gucci CEO Marco Bizzarri, explained that the era of luxury exclusivity has come to an end, leaving room for a much broader and more varied concept. The exclusivity of the world of luxury is false and is now over, explained the manager, and the alternative is to focus on the opposite concept, that of inclusiveness. ${ }^{1}$

Fashion is becoming more inclusive in terms of design, which learns from streetwear how to offer people plenty of comfort and style the whole day. In the stores, the experience has completely changed. Clerks are becoming more natural, empathetic and smiling and must now convey positive emotions. Bizzarri also discussed the work done at Gucci, with the creative director Alessandro Michele, and explained that they wanted to create a new Gucci not only in aesthetic terms but also in cultural terms. "We wanted to speak to the emotional side of our consumers, through well-conceived narratives and storytelling, to be present in their lives not only with products, but also with content and values." Inclusiveness is also driven by social networks that directly connect brands and consumers and generate a community.

Within the complex world of luxury, various authors have attempted to identify macro-segments of clients, and Allérès (1990) divided the luxury market into three distinct categories that refer to different social classes. The taxonomy developed distinguishes between inaccessible luxury, intermediate luxury and affordable luxury. Inaccessible luxury is characterized by custom-made products produced in limited numbers and distributed through a highly selective network. The prices of these products are undoubtedly very high. These products project the consumer into a dimension of rarity and unsurpassed exclusivity, offering the realization of desires reserved for a small circle. Hence, inaccessible luxury is the tip of the pyramid. This class is associated with haute couture collections and precious items and reflects the idea of luxury established before the advent of the "new luxury." Intermediate luxury products have a lower degree of uniqueness than inaccessible ones; they are produced in small quantities and distributed through selected sales

\footnotetext{
${ }^{1}$ https://www.pambianconews.com/2018/10/30/bizzarri-finita-lera-dellesclusivita-e-lora-del-lussoinclusivo-246868/.
} 
channels; they are sold at a price that, although high, does not reach the same levels of inaccessibility as those of the upper class. This category includes prêt-à-porter and ready-to-wear collections that better fit the idea of "new luxury." Finally, affordable luxury includes products that allow a wider range of consumers to get closer to the emotional experience of buying luxury products. The extension of the luxury brand in categories such as perfumery, eyewear and cosmetics is a typical way to enter the world of luxury even for those who cannot afford to spend large amounts.

In line with this pyramidal perspective, Kapferer's (2012) study in its analysis of business models highlights four different levels of brands. At the top is the "griffe," which conceptually approaches the previously illustrated theory of inaccessible luxury. The brand was described by Kapferer as a signature on a unique work. In a single definition, the author encompasses the image of uniqueness and craftsmanship: we are in the realm of art and not of simple style. The materialization of this perfection leads the consumer to feel like the protagonist of an elitist dream. At the second level, there are "luxury brands" produced in limited series with a very high quality. This lower step incorporates the output of simplified mass production in which the level of industrialization is higher. In this range of products, brand awareness generates intangible added value for expensive and premium quality products. At the base of the pyramid are branded goods produced in large quantities and sold at a lower price to a wider range of consumers. The limitation of this business model lies in the fact that the more the lower categories and products expand at an affordable price, the more there is a risk of moving away from the top of the pyramid and, therefore, from the creativity and valuable heart of the brand.

Finally, it should be stressed once again that the notion of luxury is subject to significant relativity, identified on the basis of several factors, and that it is still evolving. Despite the globalization of fashion industry, the definition of luxury goods and services remains, at least partially, contingent on the gender, age and geographical areas considered. This is because of the various degrees of evolution and penetration of luxury in mature or emerging markets. Other elements that might come into play are socio-demographic or psychographic variables up to the individual 
level such that the concept of luxury is modified on the basis of perceptions, motivations and attitudes (Mattia 2013). The concept of luxury, like a diamond, has many facets and multiple colors, which change on the basis of the perspective from which it is scrutinized.

\subsubsection{The Attributes of Luxury Goods}

The aforementioned considerations clearly emphasize that clients are willing to pay a premium price for luxury products. Nevertheless, it would be reductive to dwell only on the price variable to identify luxury products. Price is one of the most important attributes; it is a necessary condition for luxury but not a sufficient condition. In attempting to outline what else represents luxury, one can identify some characteristics considered as basic minimum requirements. As many authors point out (Fabris 2003; Corbellini and Saviolo 2015), luxury is a plexus of meanings that largely transcends economic value and perfectly calibrates a mix of attributes. The luxury brand experience is never characterized by a single trait; it is multifaced and the result of a mix of innovation and creativity, tradition and history, superior quality and high prices, exclusive communication and selective distribution, the imaginary and storytelling. Particularly in the fashion industry, luxury combines product attributes, creativity and brand image.

The literature identified many recurring attributes of luxury fashion products. The brand name, identity, status, reputation and awareness as well as product and design attributes such as quality, craftsmanship, innovation, uniqueness and creativity are considered fundamental (Chevalier and Mazzalovo 2008; Erickson and Johansson 1985; Jackson 2004; Moore and Birtwistle 2005; Nueno and Quelch 1998; Okonkwo 2007; Phau and Prendergast 2000).

Luxury products are often also perceived as rare, and selectivity is to be understood not only at the product level but also from the perspective of the customer, who feels he belongs to a small circle of elected representatives: "the happy few" (Kapferer 1997). Some luxury products are adapted to clients' personal needs, and no one else will have access to 
the same. Custom-made products enhance the sense of exclusivity that a luxury product can offer.

These attributes must be managed concurrently and require a consistent and coherent approach to create and maintain a luxury fashion brand positioning. Excellent quality along with high prices is one of the most cited luxury features and identifies the presence of unique and precious raw materials or manufacturing processes characterized by great professionalism and rare craftsmanship.

Reliability and perceived durability lead the consumer to an attitude of trust so that there is no fear of defects. Upon extremizing the concept, we can say that a luxury product is associated with an image of perfection and eternity.

These features generate iconic products that have typified exclusive, aspirational characteristics. The interpretation and mixture of each of these attributes generates the so-called brand signature or 'brand DNA,' the company spirit that enhances rarity, exclusivity, visibility and uniqueness and in which clients find a means to express themselves. In this respect, communication and distribution strategies are central to correctly and coherently tell, share and sustain the brand DNA. Luxury stores are considered shopping cathedrals; they enjoy significant investments, are considered crucial to a brand's marketing and reputation and do not merely support brand sales. Therefore, luxury companies often own stores to increase the control over customer relationship and experience at the point of sale.

Nevertheless, despite the importance and growth of the luxury sector, empirical investigations of the dimensions of luxury attributes and their connections and development are still underdeveloped.

For example, nowadays, keywords such as 'sexiness,' which identifies the ability to express a new sensuality in a clear break with past canons, or 'genderless' are widely reported by industry experts and might contribute to the growth of the luxury sector (Madsen 2018; Luna and Barros 2019). 


\subsubsection{Brand Heritage}

Brand heritage is still considered a relevant notion and brand DNA is grounded on each specific firm's heritage (Beverland 2004; Moore and Birtwistles 2005). In the consumer's mind, luxury products must have a story to tell and a tradition to respect, conveying the idea of something precious and refined. Many luxury brands, such as Chanel or Dior, have a long history and their success still relies on their ability to build products based on their icons, such as the tailleur or pearls of Chanel or the structured midi dresses of Dior. The investment in the culture or spirit of a luxury firm ultimately supports the brand.

Today, this topic is a matter of a vivid debate. New generations and technologies have somehow questioned the ability of products built on a firm's heritage to address rapidly changing needs and lifestyles. Today, managers wear sneakers to work. Is that coherent with the heritage and brand image of Chanel? Luxury brands are undergoing a phase labelled "re-branding," which signals the need to profoundly revise the brand image to cater to the most crucial 'Millennial' needs and expectations. In this respect, many managers and $\mathrm{CEO}$ interviews suggest a different interpretation of the "re-branding" phenomenon. Some see a profound disengagement with the past such that brands and new designers, such as Alessandro di Michele in Gucci, Virgil Abloh in Vuitton or Demna Gvasalia in Balenciaga, are rewriting these brands' DNA. Others see profound changes and multiple radical innovations in brand names, such as Yves Saint Laurent becoming Saint Laurent. In terms of the content of collections, they see the relevance of street style and the timing of collections. For example, Alexander Wang exited the New York fashion week but still believes that brand success is rooted in its heritage.

For example, Fionda and Moore (2009) conducted a multiple case study and found that clear brand identity is a crucial distinctive attribute of luxury brands and that the fashion element of each brand has significant correlation with brand values. They also emphasize the importance of design signature along with iconic products and the history and heritage of a luxury brand, which are considered crucial as they bring an element of authenticity. 
The "re-branding" process driven by the rise of young and talented designers also leads to the question of whether the brand or the designer comes first. This question has always accompanied the history of luxury. Until now, however, the principle of the continuity of the Maison has been guaranteed: no matter how innovative, each change made by the designer has had to deal with the heritage of the brand and in some way adapt to what it represented before them and would represent after them. This balance, however, seems to have been overlooked. Clear examples are two fashion shows, that of Riccardo Tisci in Burberry and that of Hedi Slimane in Céline in 2018. Both led the catwalk with clear messages of the 'zeroing' of what had preceded them through relevant variations in positioning, owing to courageous stratagems on social networks, colorful outdoor sponsorships or, again, disruptive logo changes such as that envisioned by Saint Laurent.

Zeroing, therefore, is a necessary and essential step. It is an approach born with the arrival of Alessandro Michele in Gucci, a brand in which he immediately imposed a new strategic paradigm with a creative mark of rupture, which could simultaneously match the imagination (and spending power) of Millennials. The Kering group is almost reaching the zero, even ending the era of Tomas Maier in Bottega Veneta. In light of this inescapable approach, the recent Versace case appears even more significant. Several sources have confirmed that the Medusa Maison, before moving on to Michael Kors, was carefully monitored by Kering and that the improvement of the operation was blocked on an unsurpassed rock. One hypothesis seems the difficulty of applying the zeroing strategy in Versace. As proof, Kors, as soon as the operation was announced, fully confirmed the current managerial and stylistic leadership (Shamsher 2011).

\subsection{The Luxury Fashion Industry: Global and Regional Dynamics}

The global annual revenues of the global fashion industry in 2019 accounts for $€ 1.64$ trillion, including footwear and jewelry. Among these, women's fashion accounts for the $51.5 \%$ of the overall amount. 
The fashion industry enjoyed a growth of between 4 and 5\% since 2013 and, particularly, the luxury industry witnessed gains, driven partly by the return of luxury consumption in Asia. This positive growth continued at about $4-5 \%$ in 2018 and 2019 and it is expected to continue in the range of $3-5 \%$ through 2025 despite the complexity and turbulence of the global environment in which luxury firms operate (Bain and Company 2018; BOF and McKinsey 2020). These data do not consider the Coronavirus Pandemic crisis in 2020.

In 2019 , the global luxury market size was valued at $€ 281$ billion, showing a growth of 4\% from 2018 (Kering Financial Document 2019). In 2018, the most rapidly growing brand was Gucci, which experienced an increase in revenue of 36.9\% (Kering Integrated Report 2019). Interbrand $^{2}$ had the second highest growth in brand value $(+23 \%)$ among all luxury brands in 2019, followed by Dior $(+16 \%)$ and Louis Vuitton $(+14 \%)$.

In 2019, apparel represented $23 \%$ of the total personal luxury goods market, showing an increase of 5\% compared to 2018. Leather goods generated a revenue estimated at $€ 57$ billion in 2019. The category expanded at a rate of $11 \%$ between 2018 and 2019. Shoes represented $7 \%$ of the luxury market in 2019 and increased by $12 \%$ on a reported basis. Watches generated a revenue of $€ 39$ billion in 2019, representing $14 \%$ of the total personal luxury goods market, and the revenue was up by $1 \%$ versus 2018 . Finally, revenue from jewelry increased by $12 \%$ in 2019 to reach $€ 21$ billion, representing $7 \%$ of the personal luxury goods market (Deloitte 2019).

In 2019, the retail channel's directly operated store network accounted for sales amounting to $39 \%$ of the total worldwide personal luxury goods market against the $61 \%$ of the wholesale channel (department stores, independent high-end multi-brand stores and franchise stores). The six most diffused sales formats were mono-brand stores $(31 \%)$, specialty stores $(20 \%)$, department stores (18\%), online stores $(12 \%)$, outlets (13\%) and airports (6\%) (Kering, Financial Document 2019).

\footnotetext{
${ }^{2}$ https://www.interbrand.com/best-brands/best-global-brands/2019/ranking/\#?filter=Luxury\&lis
} tFormat $=1 \mathrm{~s}$. 
Luxury firms are primary located in Europe, US and Asia, and Italy accounts for the highest number of luxury brands in the Interbrand ranking (24 up to 100 ).

By nationality, worldwide luxury fashion is characterized by the volume of Chinese (32\%) and American consumers (22\%). Chinese consumers increased their share by two percentage points versus 2018 . Generations Y (Millennials) and Z contributed $100 \%$ to market growth in 2019. Those of this population in China and South-East Asia are more dynamic and attracted by personal luxury goods (Kering, Financial Document 2019).

Over the past ten years, China has accounted for $70 \%$ of the expansion in the luxury fashion market segment, and this dominance is expected to continue till 2025. Example of brands that have been very successful in China are LVMH, Gucci and Lululemon, the last of which increased its revenues in China by 68\% in the second quarter of 2019. In this case, physical retail is still crucial- $85 \%$ of shoppers engage with both online and offline touchpoints compared to $80 \%$ in 2017 . Chinese consumers are expected to drive growth, with the boost provided by the rising middle-class.

Europe still accounts for $17 \%$ of sales and the other Asian countries for the $11 \%$ followed by Japan (10\%) (Kering, Financial Document 2019).

India, Philippines and Indonesia are among the fastest-growing major economies, but mainly for the modest fashion market.

Russia is the ninth largest luxury market in the world. In terms of the luxury industry, market growth faced a decline and then a stabilization, and in 2018, brands such as LVMH and Dior reported the highest sales in the region since 2014.

Furthermore, the Middle East is an established fashion market with a growth potential owing to the propensity of clients to spend substantial amounts. For example, in the United Arab Emirates (UAE), shoppers spend over six times more than Chinese shoppers (BOF and McKinsey 2020).

The Eurozone continued to experience growth albeit at a slower pace in 2018 and faced a decrease of 1\% in the middle of 2019. Spain and France have outperformed the Eurozone, with Germany and Italy experiencing slight contractions in their growth. The cause of this deceleration 
can be attributed to higher energy prices, a high-valued Euro, trade uncertainty and weakened global demand. The Eurozone has undoubtedly been impacted by the trade wars between China and the US. However, the debt to the Gross Domestic Product (GDP) in the Eurozone has also contributed to the slow growth. Despite this backdrop, the Eurozone has reached its highest level of employment and wage growth, fueling private consumption. Finally, the Eurozone will not be insulated from Brexit, but the exact impact is difficult to predict (Deloitte 2019).

Many factors might impact the future of the luxury industry: the recent slowdown of economic growth in many countries, the recent adoption of protectionist policies in US and China, the digital revolution and the impact of technology on production systems, the influence of Millennials and Generation Z and the Brexit in the Eurozone. Overall, estimates for 2020 are positive with growth in the number of Chinese consumers $(+10 \%)$, leather goods $(+6 \%)$ and the digital sales channel $(+13 \%)$. The marginality of high-end companies is estimated to grow by $4.5 \%$ owing to the extraordinary performance of large conglomerates. This performance is primarily due to the consolidation of the main growth drivers of recent years: the rise of Chinese consumption, the increase in expenditure by young generations and the rise of online channels (Osservatorio Altagamma 2019).

To remain competitive in this continuously evolving, complex, digital and global landscape, firms need more competences and resources. The minimum size required to survive as an independent global luxury fashion firm is estimated to be one billion euros. Smaller firms risk being trapped in a local competition that, for example, does not lead to success in countries such as China or does not benefit from e-commerce to the fullest. Therefore, from the year 2000 onwards, we have observed an increasing number of mergers and acquisitions (M\&As) in which the biggest groups, mainly LVMH and Kering, are acquiring numerous luxury fashion brands, increasing the level of concentration in the industry, while smaller family firms are struggling to survive. 


\subsubsection{Competitiveness and Mergers and Acquisitions}

Since the mid-1980s, many companies operating in the luxury sector have started increasing investments in M\&As to promote rapid growth and increase their competitiveness. Year after year, this process increased the level of the concentration of the luxury fashion industry, especially in Europe, where several smaller family businesses are located. These firms, such as Gucci or Fendi, have a strong brand image, reputation, a clear value proposition and positioning but also lack the resources to face threats and opportunities mainly related to the emergence of new markets and new technologies.

In 2000, M\&A operations had reached considerable numbers, but in the last twenty years, they have more than doubled. LVMH, Mayhoola, Kering and Michael Kors are examples of groups that have undertaken the most important and expensive acquisitions in the past twenty years, creating portfolios of brands extremely diverse to make their market position robust.

Among the most valuable acquisitions were the Kering purchase of $42 \%$ of the Gucci Group for $\$ 3$ billion in 1999, the acquisition of Christian Dior in 2017 for $\$ 13.7$ billion by the Arnault family, the Michael Kors acquisition of Versace for $€ 1.83$ billion in 2018 (Euronews) and the Mayhoola (a company owned by a leading investor in Qatar) acquisition of Valentino for $€ 858$ million in 2012 (Sowray 2012).

The study "Fashion Luxury Private Equity and Investors Survey 2019" conducted by Deloitte highlights precisely this race for consolidation in the luxury market and the growing interest of investors in the sector. A total of $265 \mathrm{M} \& \mathrm{~A}$ transactions in the world of luxury were recorded in 2018, of which 73 focused on luxury fashion and took place mainly in Europe (Deloitte 2019). Large groups continue acquiring fashion companies with valuable reputations, assets, and a well-defined heritage. They provide them substantial financial resources to promote their brand and develop their vision worldwide. Companies have begun acquisitions of new and consolidated brands to seek different identities and continue their growth by serving multiple segments. 
In Europe, two market leaders, namely the conglomerates LVMH and Kering (formerly PPR), acquired many brands in different industries ranging wine to jewelry but mainly focused on fashion. Today, they have a rich portfolio of brands and the structure of the luxury market is almost oligopolistic.

The name LVMH itself was generated from the merger between Moët Hennessy and Louis Vuitton in 1987. In 1988, LVMH acquired Céline and from 1999 onwards, it started a comprehensive internationalization process, purchasing 25 leading brands. In the fashion and leather goods division, the Maison has 18 brands which, in 2018, recorded sales of $€ 18,455$ million: Berluti, Céline, Christian Dior, Emilio Pucci, Fendi, FENTY, Givenchy, Kenzo, Loewe, Loro Piana, Louis Vuitton, Marc Jacobs, Moynat, Nicholas Kirkwood, Patou, Pink Shirtmaker and RIMOWA.

Kering's most important initial acquisitions were those of the Gucci group and Yves Saint Laurent in the 1999. This was followed by those of Bottega Veneta and Balenciaga. Partnerships were also forged with artists such as Stella McCartney and Alexander McQueen. In 2005, FrançoisHenri Pinault became the new President and CEO of PPR, which revolutionized the group due to the sale and acquisition of Maison Fancy. In 2013, Pinault transformed the PPR group into Kering. Currently, the division of Couture and Leather Goods owns the following brands: Gucci, Bottega Veneta, Saint Laurent, Alexander McQueen, Balenciaga and Brioni.

These acquisitions almost always preserve the brand's creative independence and identity but also add support functions that are centralized at the corporate level and serve all brands. Currently, ICT and finance are examples of centralized functions. Moreover, several projects, for example, in the sustainability field are developed centrally and support all brands. Less information is available about the development of economies of scale and scope for primary activities such as production or logistic, which are still often decentralized at the brand level. 


\subsection{Conclusions}

This chapter has provided a definition of luxury and a detailed discussion of how it has changed in time till arriving at the concepts of new luxury and zeroing. Thereafter, this chapter has also offered an overview of the industry, its performance and its major regional trends. Finally, the chapter has provided a description of the industry's concentration process driven by merger and acquisitions.

The chapter shows how the notion of luxury is subject to significant relativity, identified on the basis of several factors, and how this concept it is still evolving. Inaccessible luxury was characterized by custom-made products produced in limited numbers and distributed through a highly selective network. The "new luxury" has a lower degree of uniqueness and it is more inclusive and nearer to our everyday life, especially to that of Millennials. Coherently, luxury brands are undergoing a phase labelled "re-branding," or zeroing, which signals the need to profoundly revise the brand image to cater to the most crucial 'Millennial' needs and expectations.

Despite the globalization of fashion industry, the definition of luxury goods remains, at least partially, contingent on the age, sociodemographic or psychographic variables up to the individual level. The concept of luxury has more facets than expected, which change in time and on the basis of the perspective from which it is scrutinized.

The growth of the luxury market worldwide has increased the interest among researchers and the number of studies on the marketing of luxury products has increased. Particularly in the last years we observed a growth of the Chinese, Indian and Middle East markets. As luxury markets expand globally, more cross-cultural research is needed to better understand how clients' behavior and needs are impacted by their country-specific culture.

Another question relevant to global expansion is till what extent luxury fashion firms can standardize their offering worldwide. Firms can develop multiple collections targeted to different countries or try to push more "global" collections. This is a crucial point especially for smaller firms with limited resources. Interestingly, this is a relevant topic that once again recalls the need to understand how the concept of luxury is 
continuously evolving: can remain garments available worldwide and, at the same time, be perceived as rare enough to be desirable? Also in this case the answer may be country specific.

Globalization has led to the shift from small family-owned businesses to multinational enterprises, such as LVMH and Kering, through M\&A strategies and the building of global value chains, new distribution channels, a democratization in the approach toward consumption, and the rise of so-called "accessible luxury".

In this scenario of new luxury and global growth, bigger firms and groups are those better equipped to face many raising opportunities and threats. How do they operationalize the new luxury concept? Who are their main clients and how do they satisfy their rising needs with emerging technologies? These are still underdeveloped research areas and the next chapter will offer some insights and answers.

Nevertheless, while the growth of emerging markets has protected the luxury sector from the global economic crisis in 2008, in 2020 the industry globalization and performance are challenged by Coronavirus. We do not now yet which will be the exact impact of this Pandemic crisis over the industry growth and how long it will last. We can expect that this crisis may led to further polarization between bigger and smaller firms, firms with healthy and critical balance sheets prior to the crisis, firms with digital capacity and online platforms and firms dependent on wholesalers, firms that learned to communicate with clients via social media and firms still focused on the relevance of fashion shows, firms with more agile supply chains and firms with long supply chains that may face long shortage.

\section{References}

Allérès, Danielle. 1990. Luxe-Stratégies marketing. Paris: Economica.

Altagamma. 2019. Altagammma 2019 worldwide market Monitor, available at https://altagamma.it/studi-e-ricerche/. Accessed on 27 Jan 2020.

Bain and Company. 2018. The personal luxury goods market delivers positive growth in 2018 to reach $€ 260$ billion-A trend that is expected to continue 
through 2025, available at https://www.bain.com/about/media-center/pressreleases/2018/fall-luxury-goods-market-study/. Accessed on 12 Oct 2018.

Beverland, Michael. 2004. Uncovering 'the theories- in-use': Building luxury wine brands. European Journal of Marketing 38 (3/4): 446-466.

BOF and McKinsey. 2020. The state of fashion 2020, available at https:// www.mckinsey.com/ /media/McKinsey/Industries/Retail/Our\%20Insights/ The $\% 20$ state $\% 20$ of\%20fashion $\% 202020 \% 20$ Navigating\%20uncertainty/

The-State-of-Fashion-2020-vF.ashx. Accessed on 10 Feb 2020.

Brun, Alessandro, and Cecilia Castelli. 2013. The nature of luxury: A consumer perspective. International Journal of Retail \& Distribution Management 41 (11-12): 823-847.

Chevalier, Mazzalovo, and Gérard Mazzalovo. 2008. Luxury brand management: A world of privilege. Singapore: Wiley.

Corbellini, Erica, and Stefania Saviolo. 2015. Managing fashion and luxury companies. Firenze: Rizzoli ETAS.

Danziger, Pamela. 2005. Let them eat cake: Marketing luxury to the masses-As well as the classes. Chicago: Dearborn Trade Publishing.

Deloitte. 2019. Fashion \& Luxury Private Equity and Investors Survey 2019, available at https://www2.deloitte.com/it/it/pages/about-deloitte/forms/glo bal-fashion-luxury-form-registrazione.html. Accessed on 27 Jan 2020.

Erickson, Gary M., and Johny K. Johansson. 1985. The role of price in multiattribute product evaluations. The Journal of Consumer Research 12 (2): 195199.

Fabris, Giampaolo. 2003. Il nuovo consumatore: verso il postmoderno. Milano: Franco Angeli Editore.

Kering, Financial Document. 2019, available at https://keringcorporate.dam. kering.com/m/5950e4d285ac1f9a/original/2019-Financial-Document.pdf. Accessed on 17 Jan 2020.

Fionda, Antoinette M., and Christopher M. Moore. 2009. The anatomy of the luxury fashion brand. Journal of Brand Management 16 (5-6): 347-363.

Jackson, Tim. 2004. A contemporary analysis of global luxury brands. In International Retail Marketing, edited by Bruce M., Moore C., \& Birtwistle G., pp. 155-169. Oxford: Elsevier.

Kapferer, Jean-Noël. 1997. Managing luxury brands. Journal of Brand Management 4 (4): 251-259.

Kapferer, Jean-Noël. 2012. The new strategic brand management: Advanced insights and strategic thinking. London: Kogan Page. 
Kering Integrated Report. 2019, available at https://keringcorporate.dam. kering.com/m/51136a84f2c9e1 fa/original/2018-Integrated-Report.pdf. Accessed on Feb 2020.

Lipovetsky, Gilles, and Elyette Roux. 2003. Le luxe éternel. De l'âge du sacré au temps des marques. Paris: Gallimard.

Luna, Camilla P., and Denise F. Barros. 2019. Genderless fashion: A (still) binary market. Latin American Business Review 20 (3): 269-294.

Madsen, Anders C. 2018. Is The Fashion Industry Really Committed to the Eradication of Gender-Specific Dressing?. Vogue, available at https://www. vogue.co.uk/article/genderless-fashion. Accessed on 4 Mar 2020.

Mattia, Giovanni. 2013. Il neo-lusso. Milano: Franco Angeli S.r.l.

Moore, Christopher M., and Grete Birtwistle. 2005. The Burberry business model: Creating an international luxury fashion brand. International Journal of Retail \& Distribution Management 32 (8): 412-422.

Nueno, Jose L., and John A. Quelch. 1998. The mass marketing of luxury. Business Horizons 41 (6): 61-69.

Okonkwo, Uche. 2007. Luxury fashion branding. Hampshire: Palgrave Macmillan.

Osservatorio Altagamma. 2019. Comunicato dell'Osservatorio Altagamma, available at https://altagamma.it/img/osservatorio-2019/1-Comunicato_O SSERVATORIO_ALTAGAMMA_2019.pdf. Accessed on 23 Jan 2020.

PambiancoNews. 2018. Bizzarri: Finita l'era dell'esclusività. È l'ora del lusso inclusivo, available at https://www.pambianconews.com/2018/10/30/biz zarri-finita-lera-dellesclusivita-e-lora-del-lusso-inclusivo-246868/. Accessed on 3 Mar 2020.

Phau, Ian, and Gerard Prendergast. 2000. Consuming luxury brands: The relevance of the rarity principle. Journal of Brand Management 8 (2): 122-138.

Shamsher, Aliyah. 2011. When luxury brands go digital, available at http://sparksheet.com/can-engagement-and-exclusivity-go-hand-in-handwhen-luxury-brands-go-digital/. Accessed on 25 May 2017.

Silverstein, Michael J., Neil Fiske, and John Butman. 2008. Trading up: Why consumers want new luxury goods-And how companies create them. New York: Penguin/Portfolio.

Sombart, Werner. 1967. Luxury and capitalism. Ann Arbor, MI: University of Michigan Press.

Sowray, Bibby. 2012. Valentino sold to Qatar royal family for $£ 556$ million, Fashion Telegraph, available at http://fashion.telegraph.co.uk/news-features/ 
TMG9397101/Valentino-sold-to-Qatar-royal-family-for-556-million.html. Accessed on 27 Jan 2020.

\section{Websites}

Michael Kors buys Versace for $€ 1.83$ billion, available at https://www.eur onews.com/living/2018/09/25/michael-kors-buys-versace-for-1-83-billion. Accessed 27 Jan 2020. 